\title{
Colorectal neoplasia in juvenile polyposis or juvenile polyps
}

Francis M Giardiello, Stanley R Hamilton, Scott E Kern, G Johan A Offerhaus, Pearl A Green, Paul Celano, Anne J Krush, Susan V Booker

\begin{abstract}
Juvenile (retention) polyps are usually solitary lesions in the colorectum but may be multiple in juvenile polyposis. The association between juvenile polyps and colorectal neoplasia is controversial. We present three patients with juvenile polyposis who had colorectal adenomas or adenomatous epithelium in juvenile polyps at ages 3,4 , and 7 years. In a retrospective study of 57 additional patients with one or more juvenile polyps, 10 patients (18\%) had colorectal neoplasia including three with adenocarcinoma, two with tubular adenoma, and six with adenomatous epithelium in a juvenile polyp (one had both adenomatous epithelium and an adenocarcinoma). Nine of these 10 patients had juvenile polyposis defined by the presence of at least three juvenile polyps; and eight of the nine had a family history of juvenile polyps. Colorectal neoplasia occurred at young age (mean (SEM) 37 (5) years).

Our findings suggest that patients with juvenile polyps who have three or more juvenile polyps or a family history of juvenile polyps should undergo surveillance for colorectal neoplasia.
\end{abstract}

The term 'juvenile polyp' was used by Horrilleno in 1957 to designate histologically distinctive colorectal polyps that usually occurred as solitary lesions in children. ${ }^{1}$ However, other authors reported that multiple juvenile polyps representing juvenile polyposis can occur, not only throughout the colorectum ${ }^{2-9}$ but also occasionally in the small bowel and stomach. ${ }^{10-12}$ In addition, families with juvenile polyposis in several members have been reported. Analysis of a limited number of such juvenile polyposis families revealed variability among pedigrees in location of gastrointestinal tract polyps and heritability of this condition. ${ }^{13} 14$

Juvenile (retention) polyps are generally thought to be hamartomatous lesions with little malignant potential. Consequently, a conservative approach toward treatment, involving only removal of the polyp, has been taken. Some reports, however, have documented the occurrence of colorectal adenomas and carcinomas in patients with single juvenile polyps as well as in those with juvenile polyposis. ${ }^{34} 12$ 15-24 Thus the nature of the association between juvenile polyps and colorectal neoplasia is controversial.

Between 1984 and 1990, four young children (ages 4-7 years) with juvenile polyposis were evaluated at our institution. Three of these four children were found to have a colorectal ade- noma or adenomatous epithelium in a juvenile polyp. Therefore, to assess the frequency of colorectal neoplasia and identify features associated with its occurrence, patients with one or more juvenile polyps at The Johns Hopkins Hospital from 1972 through 1980 were reviewed.

\section{Methods}

PROSPECTIVE STUDY

Four children with juvenile polyposis evaluated at The Johns Hopkins Hospital from 1984 through 1990 were identified prospectively. The computerised surgical pathology diagnosis file in the department of pathology was searched systematically, but no additional cases were found in this time period. The clinical records and pathological material of the four cases were reviewed.

\section{RETROSPECTIVE STUंDY}

We investigated the association between juvenile polyps and colorectal neoplasia by retrospective review of all juvenile polyp cases identified by searching the surgical pathology files and The Johns Hopkins Bowel Tumor Registry for the nine year period of 1972 through 1980 . The histopathological sections of the polyps were reviewed by a gastrointestinal pathologist (SEK/SRH) to confirm the diagnosis using established criteria. ${ }^{35}$ Fifty seven patients with one or more juvenile polyps were identified. All polyps were located in the colorectum. Each patient's medical records and a mailed questionnaire to patients and their physicians were also evaluated.

Patients were distinguished as familial or non-familial cases on the basis of family history of juvenile polyp(s). Family history was considered positive for juvenile polyp(s) if at least one first degree relative was affected as verified by physician contact. Patients were considered to have juvenile polyposis if they had three or more colorectal juvenile polyps. Colorectal neoplasia was considered to be present if the patient had an adenocarcinoma, an adenoma, or adenomatous epithelium in a juvenile polyp in the large bowel. All cases with colorectal neoplasia were verified through histopathological review by both gastrointestinal pathologists (SEK and SRH). Polyps of three familial and one nonfamilial patient judged indefinite for adenomatous epithelium were regarded as negative in the analysis of results.

In addition to the 57 cases that fulfilled our criteria and formed the present study popula- 
tion, 11 patients identified in the same period with a polyp histologically consistent with juvenile polyp were excluded. These cases had a history of inflammatory bowel disease $(n=9)$ or polyps occurring at an anastomotic site from previous surgery $(n=2)$ and were judged to have inflammatory polyps rather than juvenile polyps.

Our findings were also compared with literature reports of patients with juvenile polyps. Literature search from 1966 to 1990 was performed through MEDLINE, accessed via the BRS Colleague Search Service. ${ }^{36}$

\section{Results}

PROSPECTIVE STUDY

Four children with juvenile polyposis were seen at The Johns Hopkins Hospital between 1984 and 1990 . The cases are summarised in table 1 and illustrated in fig 1 . Rectal bleeding was the presenting complaint in each case. The ages at diagnosis of juvenile polyposis by colonoscopy with biopsy or polypectomy were $3,4,6$, and 7 years old. All patients were female. There was no family history of juvenile polyps, juvenile polyposis, or colorectal cancer in any of these cases. Adenomatous epithelium was present in

Table 1 fuvenile polyposis cases in 1984-90

\begin{tabular}{|c|c|c|c|c|}
\hline & Case $A$ & Case $B$ & Case $C$ & Case D \\
\hline $\begin{array}{l}\text { Age at diagnosis of juvenile polyposis (years) } \\
\text { Race: white (W)/black (B) and sex } \\
\text { Family history of juvenile polyposis } \\
\text { Age at diagnosis of colorectal neoplasia (years) } \\
\text { Family history of colorectal cancer } \\
\text { Type of neoplasia }\end{array}$ & $\begin{array}{l}3 \\
\text { WF } \\
\text { No } \\
3 \\
\text { No } \\
\text { Adenomatous } \\
\text { epithelium in } \\
\text { juvenile polyp(s) }\end{array}$ & $\begin{array}{l}4 \\
\text { BF } \\
\text { No } \\
4 \\
\text { No } \\
\text { Adenomatous } \\
\text { epithelium in } \\
\text { juvenile polyp(s), } \\
\text { tubulovillous adenoma }\end{array}$ & $\begin{array}{l}6 \\
\text { WF } \\
\text { No } \\
\overline{\text { No }} \\
\text { None }\end{array}$ & $\begin{array}{l}7 \\
\text { WF } \\
\text { No } \\
7 \\
\text { No } \\
\text { Tubulo- } \\
\text { villous } \\
\text { adenomas }\end{array}$ \\
\hline Type of specimen & Polypectomy & $\begin{array}{l}\text { Polypectomy, } \\
\text { colectomy }\end{array}$ & Polypectomy & Colectomy \\
\hline Neoplasia sites in colon & $\begin{array}{l}\text { Rectum, } \\
\text { transverse }\end{array}$ & $\begin{array}{l}\text { Rectum, } \\
\text { sigmoid, } \\
\text { ascending }\end{array}$ & None & $\begin{array}{l}\text { Rectum, } \\
\text { transverse }\end{array}$ \\
\hline
\end{tabular}
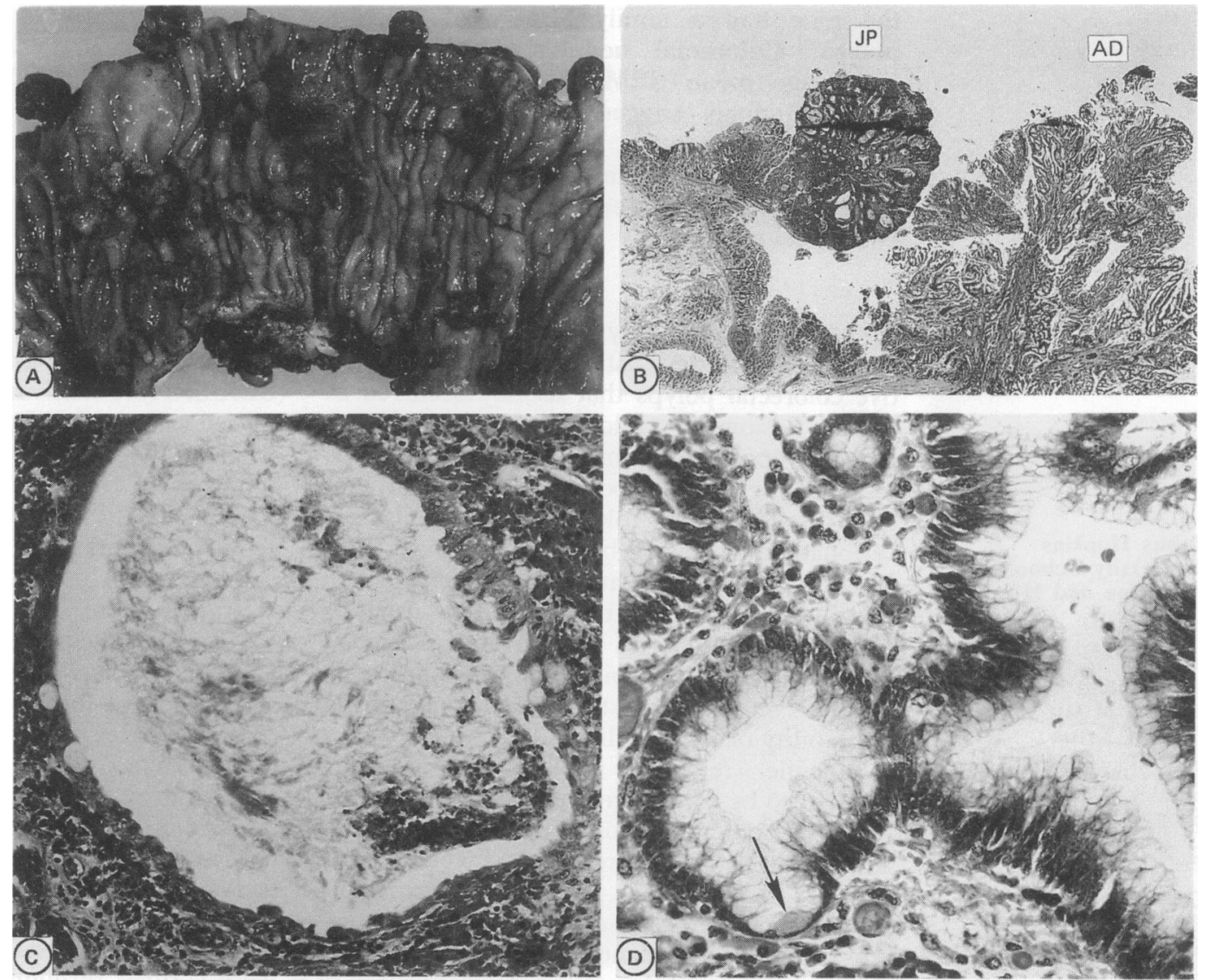

Figure 1 Colectomy specimen from case B in table 1. (A) Gross photograph shows numerous polyps of varying sizes and configurations $(\times 0 \cdot 6)$. (B) Photomicrograph of juvenile polyp $(\mathcal{F} P)$ and separate tubulovillous adenoma $(A D)$ in the ascending colon. The frond like appearance of the adenoma is strikingly different from the ovoid juvenile polyp (haematoxylin and eosin, $\times 45)$. (C) High power photomicrograph of juvenile polyp in (B). The dilated gland contains fibrinoinflammatory exudate and has flattended epithelium. The surrounding stroma consists of inflamed granulation tissue. No adenomatous epithelium is present (haematoxylin and eosin, $\times 190)$. (D) High powver photomicrograph of tubulovillous adenoma in $(B)$. The epithelium is hypercellular with stratified, spindle shaped nuclei. Proliferated paneth cells (arrow) are present in the neoplastic epithelium (haematoxylin and eosin, $\times 380$ ). 
juvenile polyps removed by polypectomy from two children at ages 3 and 4 years old (cases $A$ and $B$ in table 1). Two children underwent colectomy for persistent bleeding (cases B and D). In case B, who had adenomatous epithelium in juvenile polyps at age 4 , a tubulovillous adenoma which had not been identified by two previous colonoscopies was present in the colectomy specimen at age 7 (fig 1). In the other child (case D) two adenomas that had not been detected by a previous colonoscopy with multiple biopsies were identified in the colectomy specimen at age 7 .

\section{RETROSPECTIVE STUDY}

The demographics of the retrospective study group of 57 patients are shown in table 2. A family history of juvenile polyps in a first degree relative was present in $\mathbf{2 0}$ of 57 patients representing six different families. Eight of the 20 (40\%) patients in the familial group had colorectal neoplasia (table 3 ). This included adenocarcinoma $(n=2)$, tubular adenoma separate from juvenile polyps $(n=2)$, and adenomatous epithelium in juvenile polyps $(n=4)$. Interestingly, seven of these eight $(88 \%)$ patients with colorectal neoplasia were males. In contrast to the familial group, only two of $37(5 \%)$ patients without family history of juvenile polyps had colonic neoplasia $(\mathrm{p}<0.01)$ : both had adenomatous epithelium in juvenile polyps and one had a separate adenocarcinoma of the rectum.

In addition to family history, the finding of multiple juvenile puiyps was associated with colorectal neoplasia. Colorectal neoplasia was found in nine of 19 patients with three or more colorectal juvenile polyps, as compared with

Table 2 Characteristics of retrospective study population with juvenile polyps

\begin{tabular}{|c|c|c|c|}
\hline & $\begin{array}{l}\text { Familial }_{(n=20)}^{*} \\
\end{array}$ & $\begin{array}{l}\text { Non- } \\
\text { familial } \\
(n=37)\end{array}$ & $\begin{array}{l}\text { Combined } \\
(n=57)\end{array}$ \\
\hline $\begin{array}{l}\text { No (\%) males } \\
\text { Mean (SEM) age at diagnosis }\end{array}$ & $11(55)$ & $20(54)$ & $31(54)$ \\
\hline $\begin{array}{l}\text { of juvenile polyps (years) } \\
\text { Range } \\
\text { No (\%) with colorectal neoplasia }\end{array}$ & $\begin{array}{c}23(4) \\
3-58 \\
8(40)\end{array}$ & $\begin{array}{r}22(3) \\
2-58 \\
2(5)\end{array}$ & $\begin{array}{c}22(2) \\
2-58 \\
10(18)\end{array}$ \\
\hline $\begin{array}{l}\text { neoplasia (years) } \\
\text { Range }\end{array}$ & $\begin{array}{r}37(5) \\
6-58\end{array}$ & $\begin{array}{l}38(15) \\
23-52\end{array}$ & $\begin{array}{r}37(5) \\
6-58\end{array}$ \\
\hline
\end{tabular}

only one of 28 patients with one or two polyps $(p<0.01)$ (fig 2). When analysed, family history and multiple juvenile polyps were interrelated variables: eight patients had both. Importantly, one of two non-familial patients with colorectal neoplasia had more than $\mathbf{4 0}$ juvenile polyps in the large intestine and can be considered a new mutation of juvenile polyposis (arrow in fig 2; case 9 in table 3). This patient had both rectal adenocarcinoma and adenomatous epithelium in multiple juvenile polyps. The second patient had adenomatous epithelium in a solitary juvenile polyp. These results suggest that juvenile polyposis can be established by three or more colorectal juvenile polyps, especially if there is a family history of a juvenile polyp.

The mean (SEM) age of diagnosis of colonic neoplasia was similar in the familial and nonfamilial (37 (5) years, range 6-58; and 38 (15), range $23-52$, respectively). Neoplastic changes were diagnosed at the time of initial juvenile polyp diagnosis in four patients and during follow up in six patients. The mean length of

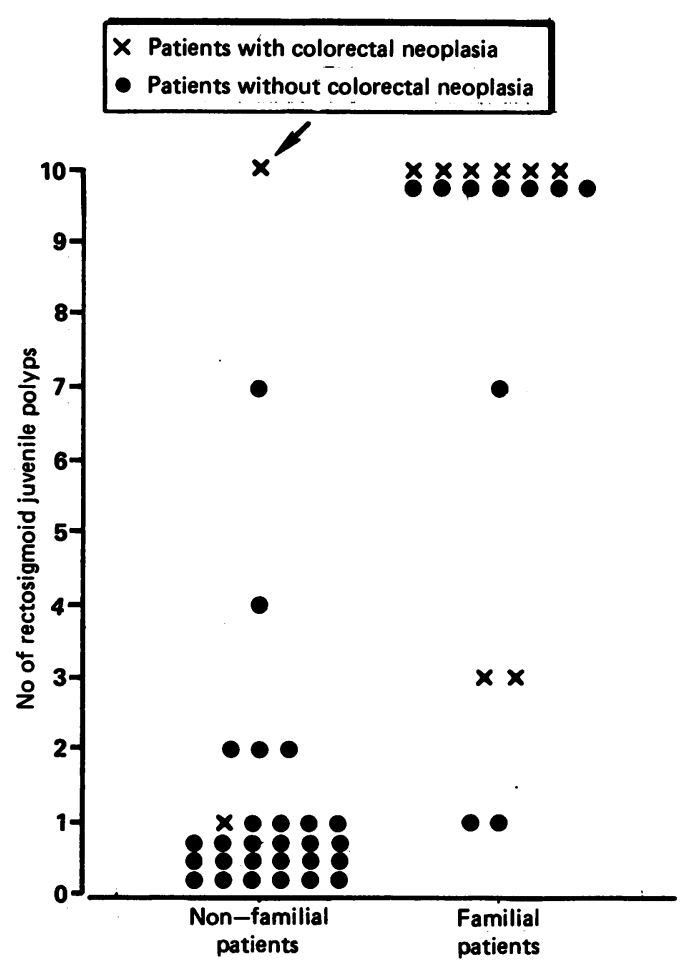

Figure 2 Occurrence of colorectal neoplasia in patients with juvenile polyp(s) in relation to family history of juvenile polyp and number of juvenile polyps.

Table 3 Characteristics of colorectal neoplasia observed in retrospective study population

\begin{tabular}{|c|c|c|c|c|c|}
\hline $\begin{array}{l}\text { Case } \\
\text { No }\end{array}$ & $\begin{array}{l}\text { Family } \\
\text { No }\end{array}$ & $\begin{array}{l}\text { Age at } \\
\text { neoplasia } \\
\text { diagnosis }\end{array}$ & Sex & $\begin{array}{l}\text { Multiple } \\
\text { jurvenile } \\
\text { polyps }(\geqslant 3)\end{array}$ & $\begin{array}{l}\text { Type/site of } \\
\text { colorectum neoplasia }\end{array}$ \\
\hline $\begin{array}{l}\text { Fami } \\
1 \\
2 \\
3 \\
4 \\
5 \\
6 \\
7 \\
8\end{array}$ & $\begin{array}{l}1 \\
3 \\
3 \\
4 \\
4 \\
5 \\
5 \\
6\end{array}$ & $\begin{array}{r}6 \\
27 \\
56 \\
42 \\
58 \\
42 \\
38 \\
26\end{array}$ & $\begin{array}{l}\mathbf{M} \\
\mathbf{M} \\
\mathbf{M} \\
\mathbf{M} \\
\mathbf{M} \\
\mathbf{M} \\
\mathbf{M}\end{array}$ & $\begin{array}{l}\text { Yes } \\
\text { Yes } \\
\text { Yes } \\
\text { Yes } \\
\text { Yes } \\
\text { Yes } \\
\text { Yes } \\
\text { Yes }\end{array}$ & $\begin{array}{l}\text { Adenomatous epithelium in juvenile polyp(s) } \\
\text { Tubular adenoma separate from juvenile polyp(s) } \\
\text { Adenocarcinoma of colon } \\
\text { Tubular adenoma separate from juvenile polyp(s) } \\
\text { Adenocarcinoma of rectum } \\
\text { Adenomatous epithelium in juvenile polyp(s) } \\
\text { Adenomatous epithelium in juvenile polyp(s) } \\
\text { Adenomatous epithelium in juvenile polyp(s) }\end{array}$ \\
\hline $\begin{array}{c}\text { Non- } \\
9 \\
10\end{array}$ & al & 23 & $\mathbf{F}$ & Yes & $\begin{array}{l}\text { Adenomatous epithelium in juvenile polyp(s) and separate } \\
\text { adenocarcinoma of rectum }\end{array}$ \\
\hline 10 & - & 52 & $\mathbf{M}$ & No & Adenomatous epithelium in juvenile polyp(s) \\
\hline
\end{tabular}


Table 4 Previous reports of colorectal neoplasia in patients with juvenile polyp(s)

\begin{tabular}{|c|c|c|c|c|c|c|}
\hline \multirow{2}{*}{$\begin{array}{l}\text { Report } \\
\text { (reference } \\
\text { Nos) }\end{array}$} & \multirow{2}{*}{$\begin{array}{l}\text { No of } \\
\text { cases }\end{array}$} & \multicolumn{2}{|l|}{ Age (years) } & \multirow{2}{*}{$\begin{array}{l}\text { Sex }(M / \\
\text { total, } \\
\% M)\end{array}$} & \multirow{2}{*}{$\begin{array}{l}\text { Family history } \\
\text { of juvenile } \\
\text { polyps (\%) }\end{array}$} & \multirow{2}{*}{$\begin{array}{l}\text { Type of } \\
\text { colorectal neoplasia }\end{array}$} \\
\hline & & Mean (SEM) & Range & & & \\
\hline \multicolumn{7}{|c|}{ Solitary juvenile polyp: } \\
\hline $16-21$ & 8 & $24(9)$ & $1 \cdot 5-67$ & $4 / 7^{*}(57)$ & $2 / 8(25)$ & $\begin{array}{l}\text { Carcinoma in juvenile polyp }(n=1) \text {, adenoma epithelium } \\
\text { in juvenile polyp }(n=3) \text {, carcinoma and adenoma in } \\
\text { juvenile polyp }(n=1) \text {, separate carcinoma }(n=1) \text {, } \\
\text { separate adenoma }(n=2)\end{array}$ \\
\hline \multicolumn{7}{|c|}{ Multiple juvenile polyps $(\geqslant 3)$ : } \\
\hline $\begin{array}{l}3,4,12,15 \\
22,23,25-34 \\
40,42\end{array}$ & 39 & $27(2)$ & $6-52$ & $25 / 38^{*}(66)$ & $15 / 39(38)$ & $\begin{array}{l}\text { Carcinoma in juvenile polyp(s) }(n=1) \text {, adenoma } \\
\text { epithelium in juvenile polyp(s) }(n=13) \text {, carcinoma } \\
\text { and adenoma in juvenile polyp(s) }(n=3) \text {, carcinoma } \\
\text { unknown site }(n=16) \text {, separate adenoma }(n=6)\end{array}$ \\
\hline
\end{tabular}

${ }^{*}$ Sex not specified in one case.

follow up was $5 \cdot 1(1 \cdot 6)$ years. When considered by pedigree all six families with familial juvenile polyposis had at least one member with colorectal neoplasia (adenocarcinoma or adenoma). However, a family history of colorectal neoplasia was noted in only two of 37 families in the non-familial group $(\mathrm{p}<0.001$ compared with familial group).

\section{Discussion}

Juvenile polyps of the colorectum have generally been considered benign hamartomas. ${ }^{16} 37-39$ Controversy concerning the malignant potential in patients with these polyps has existed for decades, however, ${ }^{1}$ because investigators have reported the occurrence of colorectal adenoma and carcinoma in patients with solitary as well as multiple colonic juvenile polyps (table 4). ${ }^{34} 12 \quad 15-24 \quad 26-3440$

The occurrence of colorectal adenomas or adenomatous epithelium in three young children with juvenile polyposis at our institution prompted us to review the association of colorectal neoplasia with juvenile polyps. There was a striking occurrence of colorectal neoplasia in juvenile polyp patients with either a family history of juvenile polyps (40\%) or with three or more rectosigmoid juvenile polyps (47\%): eight of 10 patients with neoplasia had both features. The association of colorectal neoplasia with juvenile polyposis despite the absence of family history is highlighted by case 9 (marked by arrow in fig 2; table 3). Although this patient had no family history of juvenile polyps, at age 23 years she had multiple juvenile polyps with adenomatous epithelium and a rectal adenocarcinoma. ${ }^{41}$ Similar to the young children prompting this investigation, such patients may well represent new mutations for the juvenile polyposis gene, explaining the absence of family history.

The literature supports our conclusion that juvenile polyposis is associated with colorectal neoplasia. Thirty eight of 46 reported cases of colorectal neoplasm and juvenile polyps occurred in patients with multiple juvenile polyps (table 4). Also, in a recent study Jass et al noted that 18 of $80(23 \%)$ juvenile polyposis patients (those with more than five juvenile polyps) developed colorectal cancer. ${ }^{15}$ Interestingly, $83 \%$ of these patients were male, and in our study seven of eight (88\%) patients with colorectal neoplasia and a family history of juvenile polyps were male. On the other hand, our three prospectively observed cases without a family history were female (cases A, B, D in table 1 ) as was the non-familial case in the retrospective study (case 9 in table 3, arrow in fig 2).

On the basis of our study and literature review, we recommend that, when possible, juvenile polyp patients with multiple juvenile polyps (three or more) or a family history of juvenile polyps should have a complete colonoscopic examination. Periodic surveillance by colonoscopy with multiple random biopsies of both polyps and flat mucosa every several years seems appropriate for these patients. Also, screening of first degree relatives is prudent because of the difficulty in recognising asymptomatic affected individuals. At times colonoscopic surveillance may be difficult especially in juvenile polyposis patients with numerous polyps. Colectomy is a consideration in these individuals because neoplasia may not be sampled by biopsies and polypectomies, as illustrated by case $\mathrm{D}$ in table 1 . Presently, there do not appear to be sufficient data from juvenile polyposis patients to justify prophylactic colectomy solely for the risk of colorectal carcinoma, as is done in adenomatous polyposis. However, in the presence of any other indications such as persistent rectal bleeding, colectomy is appropriate.

Although much less frequently reported, patients with solitary juvenile polyps and no family history have developed colorectal neoplasia. Our one case of this type was a 52 year old man (case 10, table 3). Literature review revealed eight cases of infants and children developing neoplasia in solitary juvenile polyps (table 4). Therefore, solitary juvenile polyps should usually be removed, even if asymptomatic, because of the small but definite neoplastic potential.

We extend our appreciation to $M$ s Linda $M$. Welch for secretarial help and Mrs Cheryl L Hamilton for data collection. Special thanks to Drs Thomas R Hendrix and John $\mathbf{H}$ Yardley for their advice and support and Dr William Moore for his assistance with the Autopsy Pathology Information Service. In addition, we extend appreciation to Drs Jay A Perman, Jonathan A Flick and David N Tuchman for help in case collection. Supported in part by The Clayton Fund, The McAshan Fund, and grant ROl CA45831 from the National Institutes of Health, Department of Health and Human Services. Dr Offerhaus is supported by grants from the Netherlands Organization for Scientific
and the Netherlands Digestive Disease Foundation.

1 Horrilleno EG. Polyps of rectum and colon in children. Cancer 1957;72:1210-20.

2 McColl I, Bussey HJR, Veale AMO, Morson BC. Juvenile polyposis coli. Proc $R$ Soc Med 1964;57:896-7.

3 Veale AMO, McColl I, Bussey HJR, Morson BC. Juvenile 
polyposis coli. F Med Genet 1966;3:5-16.

4 Lipper S, Kahn LB, Sandler RS, Varma V. Multiple juvenile polyposis. A study of the pathogenesis of juvenile polyps
and their relationship to colonic adenomas. Hum Patho and their relation

5 Smilov PC, Pryor CA, Swinton MW. Juvenile polyposis coli. Dis Colon Rectum 1966;9:248-54.

6 Haggitt RC, Pitcock JA. Familial juvenile polyposis of the colon. Cancer 1970;26:1232-8.

7 Grotsky HW, Rickent RR, Smith WD, Newsome JF. Familial juvenile polyposis coli. A clinical and pathologic study of a large kindred. Gastroenterology 1982;82:494-501.

8 Raynham WH, Louw JH. Familial polyposis of the colon. $S$ Afr Med $\mathcal{f} 1966 ; 40: 857-65$.

9 Louw JH. Polypoid lesions of the large bowel in children with particular reference to benign lymphoid polyposis. particular reference to benign

10 Watanabe A, Nagashima H, Motoi M, Ogawa K. Familial juvenile polyposis of the stomach. Gastroenterology 1979;77: 148-51.

11 Jarvinen HJ, Sipponen P. Gastroduodenal polyps in familia adenomatous and juvenile polyposis. Endoscopy 1986;18: adeno

12 Beacham C, Shields $H$, Raffensperger E, Enterline $H$. Juvenile and adenomatous gastrointestinal polyposis. Dig Dis Sci 1978;23:1137-43.

13 Watne AL. Patterns of inheritance of colonic polyps. Semin Surg Oncol 1987;3:71-6.

14 Louw JH. Polypoid lesions of the large bowel in children. $S$ Afr Med f 1972;46:1347-52.

15 Jass JR, Williams CB, Bussey HJR, Morson BC. Juvenile polyposis-a precancerous condition. Histopathology 1988;
13:619-30.

16 Stemper T, Kent T, Summers R. Juvenile polyposis and gastrointestinal cancer. Amm Intern Med 1975;83:639-46.

17 Tung-hau L, Min-chang C, Hsien-chir T, Lan C, Chien L. Malignant changes of a juvenile polyp of the colon. A case report. Chin Med f [Engl] 1978;4:434-9.

18 Billingham R, Bowman H, MacKeisan J. Solitary adenomas in juvenile patients. Dis Colon Rectum 1980;29:26-30.

19 Friedman C, Fechner R. A solitary juvenile polyps with hyperplastic and adenomatous glands. Dig Dis Sci 1982;27: hyperp 946 .

20 Philbert M, Dodat H, Bouveir R, Chappuis JP, Daudit M. Cancer recto-sigmoidiens et polypes chez l'enfant: commentaires a propos de 2 cas de polypes juveniles atypiques. Chir Pediatr 1984;25:28-31.

21 Berg HK, Herrera L, Petrelli N, Lopez C, Mittleman A. Mixed juvenile-adenomatous polyp of the rectum in an elderly patient. F Surg Oncol 1985;29:40-2.

22 Jones MA, Herbert JC, Trainer TD. Juvenile polyp with intramucosal cancer. Arch Pathol Lab Med 1987;111:200-1.

23 Velcek FT, Coopersmith IS, Chen CK, Kassner E, Koltz D, Kottmeier P. Familial juvenile adenomatous polyposis. f Pediatr Surg 1976;11:781-7.

24 Mazier P, Mackeigan J, Billingham R, Dignan R. Juvenile polyps of the colon and rectum. Surg Gynecol Obstet 1982; polyps of the

25 Fechner $R$, Mills S. Unusual adenomatous polyps in juvenile polyposis coli. Am $\mathcal{J}$ Surg Pathol 1982;6:177-83.

26 Yoshida H, Tomichi N, Mori S, et al. Juvenile polyposis coli. A case report. $\mathcal{J p n}_{p n} \mathcal{F}$ Surg 1982;12:274-9.

27 Jarvinen H, Franssila K. Familial juvenile polyposis coli; Increased risk of colorectal cancer. Gut 1984;25:792-800.

28 Bousson-Weill M, Fischer D, Reys P, Lauffenburger C, Muller J. Polypose recto-colique complexe adenomateuse et hamartomateuse avec polyps gastrique hyperplasique chez une jeune fille de 13 ans. Gastroenterol Clin Biol 1984;8: 621-6.

29 Katayam Y, Kimura M, Konn M. Cronkite-Canada syndrome associated with rectal cancer and adenomatous
changes in colonic polyps. Am $\mathcal{F}$ Surg Pathol 1985;9:65-71.

30 Gilinsky NH, Elliot MS, Price SK, Wright JP. The nutritional consequences and neoplastic potential of juvenile polyposis coli. Dis Colon Rectum 1986;29:417-20.

31 Kendall R, Vose P. Diffuse juvenile polyposis of colon: a premalignant condition? Dis Colon Rectum 1981;24: a prema 205 .

32 Monga G, Mazzucco G, Rossini F, Presti F. Colorectal polyposis with mixed juvenile and adenomatous patterns. Virchous Archiv $A$ 1979:382:355-60.

33 Rabin E, Patel T, Chien F, Gunalp S, Brown H. Juvenile colonic polyposis with villous adenoma and retroperitoneal fibrosis. Dis Colon Rectum 1979;22:63-7.

34 Kaschula R. Mixed juvenile, adenomatous and intermediate polyposis coli. Dis Colon Rectum 1971;14:368-74.

35 Kent TH, Mitros FA. Polyps of the colon and small bowel, polyposis syndromes, and the adenoma-carcinoma sequence. In: Norris TH, ed. Pathology of the colon, small intestine and anus. New York: Churchill Livingstone, 1983: 178-9.

36 Haynes RB, McKibbon KA, Walker CJ, et al. Computer searching of the medical literature: an evaluation of MEDLINE searching systems. Ann Intern Med 1985;103: 812-6.

37 Shermeta DW, Morgan WW, Eggleston J, White J, Haller J uvenile retention polyps. F Pediatr Surg 1969;4:211-5.

38 Holgersen $\mathbf{L}$, Miller $\mathbf{R}$, Zintel $H$. Juvenile polyps of the colon and rectum in children. Reviews of Surgery 1970;27.222.

39 Slim M, Alameddine A, Nassar V, Mishalany H. Rectal and colonic polyps in childhood. American fournal of Proctology 1977;28:27-32.

40 Sandler R, Lipper S. Multiple adenomas in juvenile polyposis. Am f Gastroenterol 1981;75:361-6.

41 Goodman ZD, Yardley JH, Milligan FD. Pathogenesis of colonic polyps in multiple juvenile polyposis: report of a case associated with gastric polyps and carcinoma of the rectum. Cancer 1979;43:1906-13.

42 Longo WE, Touloukian RJ, West AB, Ballantyne GH Malignant potential of juvenile polyposis coli: report of a case and review of the literature. Dis Colon Rectum 1990;33: $980-4$. 